DOI: http://doi.org/10.31617/k.knute.2019-04-12.43

Ткаченко T.I., д. е. н., професор Google Scholar https://scholar.google.com.ua/citations?user=JijfQg8AAAAJ\&hl=uk Проценко Я.В., к. е. н., ст. викл. Київський національний торговельно-економічний університет, м. Київ, Україна

\title{
ДИВІДЕНДНА ПОЛІТИКА В УПРАВЛІННІ ГОТЕЛЬНИМИ ПІДПРИЄМСТВАМИ КОРПОРАТИВНОГО ТИПУ
}

Стратегічний розвиток підприємств готельного господарства базується на забезпеченні їх фінансовій стабільності у довгостроковій перспективі. В сфері індустрії гостинності України частка підприємств, що функціонують у формі акціонерних товариств, тобто корпоративного типу, $\epsilon$ чи не найбільша у порівнянні 3 іншими видами економічної діяльності. Формування і реалізація зваженої дивідендної політики у публічних акціонерних товариствах (ПАТ) та приватних акціонерних товариствах (ПрАТ) в системі інструментів забезпечення фінансової стабільності останнім часом досить епізодично розглядається у науковій і фаховій спеціальній літературі; критерії оптимізації дивідендної політики не визначені.

Сутність дивідендної політики полягає в оптимізації пропорції між споживаною акціонерами та капіталізованою частинами прибутку для досягнення довгострокових цілей підприємства і спрямуванні на зростання ринкової вартості його акцій. Ефективна дивідендна політика повинна бути гарантом фінансової стійкості підприємства та орієнтиром для залучення інвесторів.

Дивідендна політика підприємства формується з використанням концепцій: гіпотеза Ф. Модільяні та М. Міллера [2], теорія переваги дивідендів М. Гордона, Д. Лінтнера, Е. Брігхема [3], концепція впливу податкової політики на дивідендну політику[1], »теорія клієнтури» теорія відповідності дивідендної політики складу акціонерів, »теорія сигналізування» - сигнальна теорія дивідендів [5].

На основі практичного використання основних положень концепцій вироблено три підходи до формування дивідендної політики консервативний, помірний (компромісний) та агресивний. Кожному 3 цих підходів відповідає окремий тип дивідендної політики. 
При консервативній дивідендній політиці пріоритетною метою розподілу прибутку є задоволення потреб виробничого розвитку підприємства, а не поточного споживання у вигляді дивідендних виплат. Перевагою політики цього типу $є$ забезпечення високих темпів розвитку підприємства, збільшення його фінансової стійкості.

Згідно з помірною (компромісною) дивідендною політикою у процесі розподілу прибутку поточні інтереси акціонерів за розмірами дивідендних виплат балансуються 3 потребами формування власних фінансових ресурсів для забезпечення розвитку підприємства. За цього типу дивідендної політики встановлюється мінімально стабільний розмір дивідендів з надбавкою в окремі періоди.

Агресивна дивідендна політика передбачає встановлення довгострокового нормативного коефіцієнта дивідендних виплат відносно суми прибутку, що споживається та капіталізується. Перевагою такої політики є забезпечення високої ринкової вартості акцій підприємства і формування його позитивного іміджу серед потенційних інвесторів при додаткових емісіях.

Дослідження свідчать, що підприємства готельного господарства України протягом 2012-2016 рр. проводили консервативну дивідендну політику, суть якої полягає в тому, що фонд виплат дивідендів формувався за залишковим принципом: дивіденди виплачувалися лише після того, як за рахунок чистого прибутку профінансовано інвестиційні потреби підприємства.

В умовах, що склалися нині в готельному господарстві України, при виборі типу дивідендної політики необхідно враховувати широкий спектр різноманітних чинників. Основні серед них: життєвий цикл підприємства, можливість формування фінансових ресурсів 3 альтернативних джерел, кон'юнктура ринку готельних послуг, невідкладність платежів за раніше отримані кредити, об'єктивні обмеження.

\section{Список бібліографічних посилань}

1. Фінансове забезпечення розвитку підприємств : монографія / I.О. Бланк, Г.В. Ситник та ін. - Київ : Київ. нац. торг.-екон. ун-т, 2011. $-343 \mathrm{c}$.

2. Богачев С.В. Капиталотворческая функция промышленных предприятий: монография / С.В. Богачев. - Донецк : Ин-т экономики промышленности НАН Украины, 2005. - 235 с.

3. Брігхем Е. Основи фінансового менеджменту: [перек. 3 анг.]. Київ : Молодь, 1997. 1000 с. 
4. Проценко Я.В. Пріоритети фінансової політики підприємств готельного господарства. / Вісн. ЧТЕІ. Економічні науки. Вип. I-II (69-70). Чернівці, 2018. №2. С. 235-243.

5. Слепов В.А. Финансовая политика компании / Финансы. 2003. № 9. C. 56-59. 